NBER WORKING PAPER SERIES

\title{
REAL SHOCK, MONETARY AFTERSHOCK: \\ THE SAN FRANCISCO EARTHQUAKE AND THE PANIC OF 1907
}

\author{
Kerry A. Odell \\ Marc D. Weidenmier \\ Working Paper 9176 \\ http://www.nber.org/papers/w9176 \\ NATIONAL BUREAU OF ECONOMIC RESEARCH \\ 1050 Massachusetts Avenue \\ Cambridge, MA 02138 \\ September 2002
}

The authors would like to thank Michael Bordo, Richard Burdekin, Charles Calomiris, Forrest Capie, Michael Edelstein, Charles Goodhart, Claudia Goldin, Anne Hanley, Charles Kindleberger, Larry Katz, Jon Moen, Harold Mulherin, Larry Neal, Ronnie Phillips, Peter Rousseau, Richard Sylla, John Wallis, Tom Weiss, and seminar participants at the 2001 Economic History Association, 2001 Business History Conference, the University of Wisconsin at LaCrosse, the Claremont Colleges, and the Spring 2002 NBER DAE meetings for comments. We would also like to thank the archivists at the Bank of England and Ellis Tallman for supplying data for the study. A special thanks to Sheree Leeds, the archivist at CGNU, for locating and transcribing the Business Minutes of Norwich Union for 1906 and 1907. The authors acknowledge financial support from Claremont McKenna College. The views expressed herein are those of the authors and not necessarily those of the National Bureau of Economic Research.

(C) 2002 by Kerry A. Odell and Marc D. Weidenmier. All rights reserved. Short sections of text, not to exceed two paragraphs, may be quoted without explicit permission provided that full credit, including (C) notice, is given to the source. 
Real Shock, Monetary Aftershock: The San Francisco Earthquake and the Panic of 1907 Kerry A. Odell and Marc D. Weidenmier

NBER Working Paper No. 9176

September 2002

JEL. No. E32, E58

\begin{abstract}
Economists have long studied the relationship between the real and monetary sectors. We examine the macroeconomic effects of the 1906 San Francisco earthquake, a shock that immediately reduced United States. GNP by 1.5-1.8 percentage points. The quake's impact manifested itself in gold flows, as British insurance companies paid their San Francisco claims out of home funds in the fall of 1906. The capital outflow prompted the Bank of England to raise interest rates and discriminate against American finance bills. British bank policy pushed the US into recession and set the stage for the 1907 financial crisis. The 1907 panic led to the formation of the National Monetary Commission whose proposals recommended the creation of the Federal Reserve. In this study, we identify the San Francisco earthquake as the shock that triggered the chain of events that culminated in the panic of 1907.
\end{abstract}

Kerry A. Odell

Department of Economics

Scripps College

Claremont, CA 91711

E-mail: kodell@scrippscol.edu
Marc D. Weidenmier

Department of Economics

Claremont McKenna College

Claremont, CA 91711

and NBER

E-mail: mweidenmier@mckenna.edu 
"San Francisco's \$200,000,000 'ash heap' [insurance payments] involves complication which will be felt on all financial markets for many months to come [and] the payment of losses sustained ... represents a financial undertaking of far-reaching magnitude. ..."

(London Financial Times, July 6, 1906)

While economics has a large theoretical literature explaining the interaction between the real and monetary sectors of an economy, empirical evidence on the relationship is less clear. Endogeneity between the two sectors makes it difficult to identify the effects of shocks in vector autoregressions and calibration exercises (Stock and Watson, 2001). This paper takes advantage of a natural experiment created by the 1906 San Francisco earthquake and fire to examine the effects of an exogenous real shock on financial and money markets as well as the response by a central bank.

Recent disasters such as Hurricane Andrew in 1992 and the terrorist attacks on the World Trade Centers incurred property damage of about 1 percent of U. S. GDP, but the costs of the San Francisco catastrophe were substantially higher (Wall Street Journal, October 9, 2001), ${ }^{1}$ at $\$ 350$ - $\$ 500$ million, or 1.3 to 1.8 percent of U. S. GNP in $1906 .^{2}$ Large amounts of relief flowed into the city in the weeks immediately following the disaster and, because British companies underwrote the majority of the city's fire insurance policies -- an estimated $£ 23$ million (or $\$ 108$ million) at the time -- millions of pounds worth of insurance claims were soon presented in London. The magnitude of the resulting capital outflows in late summer and early autumn 1906 forced the Bank of England to undertake defensive measures to maintain their desired level of reserves and a fixed sterling/dollar exchange rate. The central bank responded by raising its discount rate two hundred-fifty basis points between September and November 1906 and by pressuring British joint-stock companies to stop discounting American finance bills for the next 
year (The Economist, October 20, 1906, p. 1694).

Actions by the Bank of England attracted gold imports and sharply reduced the flow of gold to the United States. By May 1907, the United States had fallen into one of the shortest, but most severe recessions in American history (Friedman and Schwartz, [1963]). Thus primed for a financial crisis, already-weakened world markets crashed in October 1907 with the collapse of the Knickerbocker Trust Company in New York. The panic led to one of the most important changes in American financial architecture: the creation of the Federal Reserve System.

Using information from contemporary sources, our paper traces out the links between the San Francisco disaster and the onset of the Panic of 1907. We then employ standard VAR techniques to provide some "stylized" facts about the economic effects of a real shock. The results indicate that the real shock reverberated through the U.S. economy and had large effects on the monetary and financial sectors. The paper begins with a brief discussion of the classical gold standard, with particular reference to the price-specie-flow mechanism and the effects of gold shocks. This is followed by a historiography of the earthquake and its economic effects. We then conclude the paper with an empirical analysis of the economic effects of the real shock on monetary and financial markets.

\section{The Gold Standard and International Specie Flows}

Between 1870 and 1914, many countries adhered to a gold standard, strictly tying national money supplies to gold stocks and standing ready to redeem currency for gold at a fixed exchange rate. The operation of the gold standard had a number of implications for economic activity in open economies, as summarized in the classical adjustment mechanism. Consider the 
effects of a sudden outflow of gold from a country --caused by the payment of insurance claims, for example. Through the price-specie-flow mechanism (most famously described by David Hume in 1752), the gold outflow amounts to a reduction in the nation's money supply, and so reduces the domestic price level. As the price of domestic goods falls relative to the price of foreign goods, exports will increase, imports will decline, and the resulting trade surplus will return gold to the nation. This gold flow will reduce the foreign price level and raise the domestic price level until trade imbalances and international price differentials are eliminated (Bloomfield, 1959; Barro, 1979; Bordo, 1984; Bordo and Ellson, 1985). ${ }^{3}$

With integrated financial markets, this trade adjustment mechanism can be augmented by capital flows, whereby the reduction in the money supply from a gold outflow raises domestic interest rates. This will attract loanable funds from abroad, reversing the initial gold outflow. Central banks may also use policy tools to affect the speed with which equilibrium is reached. Under "the rules of the game," central banks are supposed to react to a sudden gold outflow by contracting the domestic money supply and raising interest rates. These policies would enhance the trade surplus and capital inflow effects of the classical adjustment mechanism, accelerating a return to equilibrium.

Prior to 1913, the United States lacked a central bank to provide liquidity during periods of monetary stringency and so the economic effects of abnormal gold flows were often magnified. Canova [1991] and Tallman and Moen [1998], building on work by Sprague [1910], argue that unusual gold flows were the cause of most financial crises and business cycles in the United States before the founding of the Federal Reserve. Canova [1991] finds that external gold shocks were an important factor in explaining fluctuations in high-powered money and economic downturns in the pre-Federal Reserve era. Tallman and Moen [1998] find evidence of a 
monetary transmission mechanism where shocks to gold high-powered money had non-neutral effects on interest rates and output in the face of sluggish price adjustment.

There is, however, far less research on the sources of exogenous gold flows. Take, for example, the many studies that have examined the causes of the Panic of 1907. Most of this literature explains the Panic as the ultimate outcome of a liquidity crisis in London resulting from excessive speculation in the New York equity market during 1906 that prompted nearly $\$ 70$ million of gold imports from England (see Sprague, [1910]; Sayers, [1963]; Clapham, [1944]; Friedman and Schwartz, [1963]; Goodhart, [1969]; Kindleberger, [1978]; Bordo and Murshid, [2000]). ${ }^{4}$ Under the gold standard, such a sudden gold outflow represented a massive shock to the British money stock. In response, the Bank of England not only doubled its discount rate but it also instituted a discriminatory policy against capital flows (in the form of finance bills) to the United States. These actions practically cut off gold exports to the United States, and England reversed its position from a net gold exporter to a net gold importer. The actions pushed the United States into a recession and made New York markets susceptible to a financial panic.

The Bank of England successfully defended the dollar/sterling exchange rate and its reserve position in the face of a sudden gold outflow. But what caused that outflow? In this paper, we utilize data from contemporary newspapers as well as internal documents from British insurance companies to suggest that insurance payments in the aftermath of the1906 San Francisco earthquake were the source of the gold shock. The payment of claims by British insurance companies to policyholders in San Francisco caused the sudden gold outflows, prompting defensive actions by the Bank of England and setting off the chain of events that culminated in the Panic of $1907 .^{5}$ 


\section{The Setting}

By the time the transcontinental railroad was completed in 1869, San Francisco had already established itself as the center for export trade from the Pacific Coast region. Endowed with an excellent natural harbor and easy coastal and river access to the agricultural and natural resource riches of the west, San Francisco had developed strong economic ties to other countries, particularly to Britain. Most of the wheat exported from the west coast and bound for England was financed through San Francisco, and a sizeable number of London banks had offices in that city.

At the same time, other British financial institutions sought to expand their business in the area. Prominent among these were the British fire insurance companies. In 1852, the Liverpool \& London \& Globe fire insurance company placed an agent in San Francisco: this was the first such insurance firm (either foreign or domestic) in the city. Two years later, three more British firms were writing business in San Francisco and the first American insurance firm set up an office in the city. It was not until 1858, however, that a San Francisco-based company was established (Kirschner, [1922]). By 1890 in California, there were 127 American fire insurance firms, each underwriting an average of $\$ 13.5$ million in risks. On the other hand, there were 52 foreign firms (more than half of which were British), each of whom underwrote $\$ 23.5$ million in risks; nearly 27 percent of California term fire insurance policies were carried by British companies. In fact, the fire insurance company writing the most policies in California was Liverpool \& London \& Globe, with total risks of \$173 million. In comparison, 28 percent of all fire insurance policy risks in New York were underwritten by foreign firms, while in Illinois foreign companies insured less than twenty percent of the value of all risks (United States 
Census, [1891]).

Twenty-five years later, these patterns persisted. At the end of 1905, slightly more than half of insured risks were underwritten by American firms, with almost forty percent of business still carried by foreign firms, most of whom were based in Britain. On the other hand, Californiabased firms were writing only seven percent of fire insurance business in the state (Kirschner, [1922]). The city of San Francisco was even more dependent on foreign fire insurers than the state as a whole. By the turn of the century, it was estimated that at least half of all fire insurance policies in San Francisco were issued by British companies (Cockerell and Green, [1976]). One explanation for the dominance of British firms is the long history of trade relations between the city and Britain; another is simple economics: as agents from the London and Lancashire insurance firm noted, the profit on San Francisco business equaled thirty percent - "three times greater than that yielded by its business generally" (Kirschner, [1922]). Evidently, adjusters failed to consider earthquake risk. ${ }^{6}$

\section{The Disaster and its Economic Effects}

On Wednesday, April 18, 1906, an earthquake of Richter magnitude 8.3 hit San Francisco. Most of the damage was not done by the tremor itself (which was especially severe in areas of landfill where liquefaction occurred) but by the fires that followed. The majority of the city's buildings had been made of wood; this material was far more plentiful and inexpensive than brick as a result of the city's central place in the coastal lumber trade. The combination of close quarters, highly flammable building materials, and earthquake-damaged water mains hampered the efforts of firefighters. Ultimately more than four square miles -- about half of the 
city -- were destroyed. Although fewer than 1,500 of the city's 375,000 residents were killed, damage was estimated at between $\$ 350$ million and $\$ 500$ million (The Commercial and Financial Chronicle, October 19, 1907).

Word of the disaster in San Francisco spread throughout the United States within hours and the impact was felt almost immediately in financial markets. In particular, news of the earthquake led to a sell-off and a significant drop in the price of shares in the New York and London stock exchanges. The New York Times of April 26, 1906 reported that the San Francisco disaster led directly or indirectly to about a $\$ 1$ billion (or nearly 12.5 percent) decline in the market value of NYSE stocks; railway stocks alone fell more than fifteen percent (The Economist, May 12, 1906). ${ }^{7}$ In London, share prices for leading insurance companies plummeted following news of the San Francisco disaster, with stock prices for most insurance companies involved in the quake suffering losses of fifteen to thirty percent in the two weeks following the disaster. Equity prices for London and Lancashire, the largest British insurer in San Francisco, posted a 30 percent decline. At the same time, shares of London Assurance fell more than onethird, from 75 to 51.5

Funds for relief and rebuilding flowed into the city quite quickly. Given the preference of Californians for specie over banknotes, these funds came largely in the form of gold ${ }^{8}$ and, in fact, San Francisco's bankers formed a clearinghouse to coordinate the distribution of gold money to their depositors shortly after the earthquake (Phillips [2002]). As shown in Figure 1, in late April and May of 1906, nearly \$50 million of gold poured into the United States from Germany, France, the Netherlands, and England (whose contribution alone amounted to $\$ 30$ million). The New York Times (May 7, 1906) and the records of the National Monetary Commission indicated that 80 percent of these funds were transferred to San Francisco; much of the rest was used to 
replenish the gold reserves of New York banks depleted by specie shipments to the West Coast. These flows were apparently also aided by the U.S. Treasury's policy of subsidizing gold imports by offering to place government deposits in banks while gold was in transit.

Because San Francisco was a major market for British fire insurance companies, however, much of the brunt of financing San Francisco's recovery was borne abroad. ${ }^{9}$ The Economist reported at length on the consequences of the disaster for British insurance firms, pointing out that they had more than $\$ 87$ million in policies in San Francisco, with an estimated \$46 million in losses (The Economist, August 11, 1906). Table 1 lists the liabilities of major insurance companies.

Of course, the amount of policies underwritten could not precisely predict the size of insurance payments to be made; some properties survived the earthquake undamaged. At the same time, the insurers (in a particularly bad public relations move) indicated early on that no payments would be made on damage that resulted from the earthquake itself. This was a sticky point: If the fires that followed the earthquake caused the damage but the fires themselves were caused by the earthquake, insurers claimed that they were not liable. ${ }^{10}$ There were no clear means of allocating damage to the earthquake or to the fire, although some insurers proposed a 60-40 split: Forty percent of each policy claim would be denied "on the ground that the destroyed buildings were first damaged in that proportion by the temblor" (the Los Angeles Times, May 8, 1906).

In contrast to relief payments, most insurance claims took months to settle as some companies equivocated while others waited for guidance from a report of the Insurance Department of New York State which outlined how American firms should settle claims. This four-point plan was not finalized until the end of July. At that time, most British fire insurance 
houses signed on and agreed to settle their claims in accordance with the New York agency. By October, it was estimated that more than $\$ 100$ million in insurance checks had been received in San Francisco (Douty, [1977]). Ultimately, British insurers paid out $£ 10$ million (\$48 million) for earthquake damage (Cockerell and Green, [1976]).

What made these British liabilities all the more significant for international financial markets was the fact that most foreign insurers decided to pay claims out of "home funds" rather than reserves in the United States. At the same time, however, the British companies were hesitant to liquidate the home securities in which they held reserves. Given the size of losses involved, such sales would undoubtedly depress stock prices. As a consequence, a number of firms negotiated term loans with their banks and so postponed securities sales for a few months (see the Financial Times, July 6, 1906).

This pattern of insurance payments can be seen in the experience of one British company, the Norwich Union Fire Insurance Society, which had over \$15 million in San Francisco policies in effect (Business Minutes of the Commercial Union Archives, [1906]) ${ }^{11}$. Following the earthquake, British firehouses gathered in London on April 20th to discuss their liability in the disaster. The great majority of British insurance companies ultimately assumed liability for fire damage caused indirectly by the earthquake. Members of the Norwich Union, however, had a special clause protecting them against losses caused by or through an earthquake. These firms initially denied any liability in the San Francisco disaster.

Because the refusal of some British firehouses to assume liability in the quake produced a large public outcry in San Francisco, members of the Norwich Union reconsidered their liability in the San Francisco earthquake. Legal counsel in the United States advised these British firehouses to pay claims in order to avoid possible litigation. Lawyers for the firehouses noted 
that British companies were likely to lose in court given that a San Francisco jury would be influenced by the "extraordinary conditions" surrounding the quake (Business Minutes of the Commercial Union Archives, May 28, 1906). Persuaded by these arguments, directors for the Norwich Union accepted liability for damage caused by the earthquake.

Some British firehouses met early claims by selling assets held by New York trust companies. Norwich Union, for example, liquidated its portfolio in July $1906{ }^{12}$ In the following months, the company utilized financial bills of exchange and even borrowed from London banks to settle insurance liabilities. Cablegrams from Mr. Hare of Norwich Union indicate that "earthquake" gold was placed on British ships and transferred to the United States.

San Francisco drafts advised 523 thousand total drafts paid 447 thousand - Balance in banks 42 thousand - May I draw? (Business Minutes of the Commercial Union Archives, September 17, 1906)

Since this morning's cablegram have additional notice of drafts so draw sight for $£ 17,571.1 .2$ time money 6 per cent, financial advice here is to borrow in London and transfer by cable -such transfer being saleable here at higher rate than sight bills. (Business Minutes of the Commercial Union Archives, September 17, 1906)

Total San Francisco drafts advised six [sic] fifty one thousand draw sight tomorrow's steamer $£ 20,682.10 .6$. (Business Minutes of the Commercial Union Archives, September 19, 1906)

Total San Francisco drafts advised 800 thousand - draw sight tomorrow steamer $£ 8,274.14 .5$. (Business Minutes of the Commercial Union Archives, October 3, 1906)

While the summer of 1906 saw British insurance firms shipping gold to San Francisco, New York financial institutions also faced low gold reserves resulting from their own specie transfers to San Francisco in the immediate aftermath of the earthquake (the Financial Times, July 6, 1906)." New York firms were also putting pressure on the Secretary of the Treasury 
Shaw to resume his policy of subsidizing gold imports by placing deposits in banks while gold was in transit. In this manner, the Financial Times predicted that New York firms would import 20 to 25 million in gold from London in the late summer and early fall of 1906.

In sum, then, the San Francisco earthquake gave rise to a massive outflow of funds -- of gold -- from London, both immediately after the earthquake and again in the autumn of 1906. As shown in Figure 2, England exported \$30 million in gold to the United States in April and May; this was followed in September and October by a further $\$ 35$ million in specie. In total, quakerelated payments to the United States represented 40 percent of seasonally-adjusted British gold exports for all of $1906^{13}$ and over 80 percent of seasonally-adjusted gold imports into the United States that year. ${ }^{14}$ These flows were nearly two-and-half times more than British gold flows to any other country in 1906.

Confirmation of the importance of insurance payments comes from gold imports into the port of San Francisco. Typically, the city accounted for a negligible amount of American gold imports in any given month. This was not the case, however, in autumn 1906. As shown in Figure 3, the city of San Francisco alone imported approximately $\$ 11$ million in the late summer and early fall of 1906. This accounted for approximately nine percent of all seasonally-adjusted U.S. gold imports in 1906. In addition, the records of the National Monetary Commission indicate that New York transferred \$10 million of gold to San Francisco in the fall of 1906. The New York Times noted on several occasions that these flows "imposed a substantial drain upon the banks of [New York]" (The New York Times, September 21, 1906). In turn, New York financial institutions imported gold from Europe to shore up bank reserves.

The magnitude of the British funds flows can be put into stark perspective by noting that they represented a 14 percent loss in the gold money stock of England. ${ }^{15}$ Faced with its largest 
two-month net gold outflow in the period $1900-1913^{16}$-- as shown in Figure 4 -- and the lowest ratio of reserves to deposits since the 1893 crisis, the Bank of England began raising its discount rate. On September 12, the rate was raised from $31 / 2$ to 4 percent; at the time The Economist (September 15, 1906) noted that "It is seldom, however, that the raising of the rate by only $1 / 2$ per cent. suffices to check an outflow of gold, and it remains to be seen whether this is going to prove an exception to the rule." In fact, it was not an exception: by October 19, the Bank had raised the discount rate to 6 percent. ${ }^{17}$ Although rates had not been at this level since 1899 , market watchers anticipated even more drastic measures to stem the outflow of gold and urged British bankers "to refrain, as far as possible, from renewing the American finance bills. . . ." 18

As shown in Figure 5, the Bank held the discount rate constant for the remainder of 1906 and then subsequently lowered it in early 1907. This would seem to indicate an easing of credit conditions in England. On the contrary, the Bank threatened joint stock companies with a 7 percent rate on money if they did not stop discounting U. S. finance bills, credit instruments used to import gold and to profit from exchange rate fluctuations. ${ }^{19}$ By December, the Bank of England had stopped discounting U.S. bills altogether, but not the bills of other countries. The Bank of England adhered to this policy until the panic of 1907 (Sprague, [1907]). ${ }^{20}$ As shown in Figure 6, these policies reversed England's position from a net gold exporter to a net gold importer by the end of 1906.

The gold drain was not confined to the London money market. Insurance companies from other parts of Europe, including France and Germany, had also issued policies in San Francisco, accounting for about 10 percent of the payments owed by foreign firms. Like their British counterparts, these firms paid their claims in accordance with the New York report (see 
The Times reports for foreign insurance companies, September-December 1906). As shown in

Figure 5, the German central bank also raised its discount rate in the fall of 1906 to counter gold losses. More important, the German and French central banks acted in concert with the Bank of England and discriminated against American finance bills for the next year (Eichengreen, [1992]). Sprague ([1910], 241) considered this action "the most important financial factor in the panic of 1907." Cross [1923] estimated that by "violating the rules of the game", European central banks had reduced the amount of finance bills in the London market from about $\$ 400$ million to $\$ 30$ million by the summer of 1907 . Reductions of similar magnitudes were also apparent on the Paris and Berlin markets. These actions stopped the flow of gold to the United States and put the squeeze on American financial markets

As finance bills came due (without the possibility for the usual rolling-over of extant bills) there was a scramble for liquidity and a sell-off of railroad securities by American firms in early 1907. The decline in stock values led to a short but sharp "Rich Man's Panic" in March, helping to push the United States into a recession. The repatriation of finance bills led to the net export of more than \$30 million in gold during the summer of 1907 (Moen and Tallman, [1990]; Tallman and Moen, [1998]). As shown in Figures 7 and 8, the U.S. gold money stock contracted nearly 10 percent between May and August of 1907 and American industrial production fell 30 percent in the second half of the year.

The New York money market entered the fall of 1907 low on gold reserves and vulnerable to shocks that might otherwise have been temporary in nature. Some scholars attribute the proximate cause of the Panic to the failed attempt by Auguste Heinz and his associates to corner the copper market. Others blame the collapse of New York's second largest trust company, Knickerbocker. Both events probably contributed to the panic that erupted in late 
October 1907, leading to a series of bank runs in New York. Within a few weeks, the crisis spread to other regions of the United States.

Several measures were taken to contain the crisis. The New York Clearinghouse Association issued loan certificates, a money substitute used to clear accounts between banks. Clearinghouse loan certificates artificially increased the money supply and freed up currency for depositors who demanded cash. Federal aid came in the form of public funds deposited by the U.S. Treasury at key New York City banks, and J. P. Morgan formed a money pool with bankers to provide liquidity assistance to trust companies and the stock market (Donaldson, [1993]; Ramirez, [1995]; DeLong, [1997]). These measures eased conditions in the money market, but failed to prevent the suspension of specie payments (Moen and Tallman, [2000]).

As short-term interest rates rose to over 10 percent --see Figure 9--, gold poured into the United States from England and the rest of Europe. Figure 1 shows that the United States imported over \$100 million in gold during November and December. Although the specie arrived too late to prevent a panic, gold shipments probably shortened the period of suspension and reduced the duration of the recession. On the other hand, specie exports drained European money centers of gold, helping to transmit the "localized" New York panic to international financial markets (Goodhart, [1969]).

To summarize, the historical narrative provides evidence that the San Francisco earthquake caused a liquidity crisis in the New York and European money markets through its effect on gold flows. The Bank of England, in conjunction with other European central banks, responded by raising their discount rates and discriminating against U.S. bills for the next year. These actions set off a chain of events -- the interest rate increases that led to a recession and stock market decline -- that ultimately ended in the panic of 1907 . We now turn to the 
econometric analysis to measure the economic effects of this unquestionably exogenous shock.

\section{Empirical Evidence}

The hypothesis put forth in this paper is that gold flows resulting from the payment of insurance claims by British and European firms to their policyholders in San Francisco had real economic effects. Specifically, the historical evidence suggests the existence of a liquidity effect through which shocks to the gold stock had non-neutral effects on interest rates and output. To examine this hypothesis, we employ a six-variable vector autoregression. We confine our analysis to the period between 1905 and 1909 to focus on the recession and panic of 1907 and to avoid including other crises such as the onset of the Russo-Japanese War in 1904.

The system includes the Bank of England's ratio of reserves to liabilities (BERATIO) [Goodhart, 1972] to measure British monetary conditions. Several studies, including Goodhart [1969] have argued that the proportion was the most important variable used in making British monetary policy decision particularly interest rates. The U.S. gold stock (GOLD), constructed from various reports of the US Treasury, is included to capture gold shocks and liquidity conditions in the United States. The Bank of England's discount rate (UKBANK) [Neal and Weidenmier, 2002] is used to capture the effects of Bank of England policy changes on the United States. This is, however, an imperfect measure of the Bank's overall policy because the bank also discriminated against U.S. finance bills. The call money rate (CALL) measures financial stress in the New York money market [Neal and Weidenmier, 2002]. U.S. industrial production (IP) is included as a measure of economic activity [Miron and Romer, 1990]. An index of U.S. wholesale prices (WPI), taken from Macaulay [1938], is employed to capture 
movements in the general price level.

Eleven dummy variables are included to control for seasonal fluctuations. A lag length of 5 is chosen on the basis of the Akaike Information Criteria (AIC). A p-dimensional vector autoregressive model with Gaussian errors can be written as follows:

$$
\mathrm{Z}_{\mathrm{t}}=\mathrm{m}+\mathrm{A}_{1 \mathrm{Z}_{\mathrm{t}-1}}+\mathrm{A}_{2} \mathrm{Z}_{\mathrm{t}-2}+\ldots+\mathrm{A}_{\mathrm{k}} \mathrm{Z}_{\mathrm{t}-\mathrm{k}}+\gamma \mathrm{D}_{\mathrm{t}}+\varepsilon_{\mathrm{t},} \quad \mathrm{t}=1, \ldots, \mathrm{T},
$$

where $\mathrm{Z}_{\mathrm{t}}$ is a $\mathrm{p} \mathrm{x} 1$ vector of stochastic variables, $\mathrm{Z}_{-\mathrm{k}+1}, \ldots, \mathrm{Z}_{0}$ are fixed, $\mathrm{D}_{\mathrm{t}}$ is a vector of seasonal dummy variables, $\mathrm{m}$ is a $\mathrm{p} \times 1$ vector of constants, and $\varepsilon_{\mathrm{t}}$ is a vector white noise process.

Granger-Causality tests are conducted following estimation of the VAR. Normally, these tests are carried out after determining whether the system is stationary in levels or first differences. However, unit root and cointegration tests have poor power and size properties, especially in short series such as ours. Therefore, we perform Granger-Causality tests first under the assumption that the system is stationary in levels and second in first differences. The results appear in Table 2 .

Several key results emerge from the Granger-Causality tests. ${ }^{21}$ The gold stock Grangercauses call interest rates and industrial production at the 5 percent level of significance in both levels and differences. Call interest rates Granger-cause industrial production at the 1 percent level in the two specifications. American interest rates also forecast changes in the Bank of England reserve ratio. This suggests the Bank of England was affected by the liquidity crisis in the New York money market during the 1906-1907 period. Another robust result is the finding that the Bank of England reserve ratio Granger-Causes industrial production at the 5 percent level in the two models. This may indicate that changes in bank policy, perhaps brought on by a 
falling level of reserves resulting from the American crisis, had important feedback effects on American business conditions. In turn, the reserve ratio Granger-causes the gold stock that adjusts in response to Bank of England policy changes. Lags of the six variables do not Grangercause the Bank of England discount rate in levels or differences, however. This is not surprising given that the central bank pursued discriminatory policies -- i.e., their decision to stop discounting U.S. finance bills for an entire year -- that did not show up in the official bank rate. Overall, the results point to a monetary transmission mechanism where shocks to gold highpowered money had non-neutral effects on interest rates and industrial production. We now turn to the impulse response analysis to examine the dynamic interactions among the variables in the system.

We estimate impulse response functions from the VAR in levels using a Choleski decomposition. $^{22}$ We order the VAR drawing from the historical narrative and Sprague's [1910] contemporary account as well as work by Canova [1991] and Tallman and Moen [1998]. The Bank of England reserve ratio and the U.S. gold stock are given the first two orderings in the VAR as shocks to these two variables precipitated defensive actions by the Bank of England. The Bank of England discount rate is given the third ordering followed by the call interest rate, industrial production, and wholesale prices. We predict that shocks to the gold stock should initially lead to a drop in interest rates (a liquidity effect), followed by a rise in industrial production. Ultimately, a shock to the gold money supply should lead to higher interest rates with an increase in the price level. Wholesale prices are therefore given the last ordering in the system to capture sluggish price adjustment.

Impulse response functions along with one-standard error bands are presented in Figure 10 to show the dynamic responses of the system to a one-standard deviation innovation in a 
particular variable. ${ }^{23}$ The results indicate the existence of a liquidity effect in which shocks to gold high-powered money had non-neutral effects on interest rates and output. An increase (decrease) in the gold stock leads to a rise (fall) in industrial production and, initially, a fall (rise) in the call rate. As the price level rises (falls), however, the gold shock leads to an increase (decrease) in interest rates. An increase (decrease) in the call interest rate leads to a significant fall (increase) in industrial production and in the price level. As for the Bank of England variables, we find that an increase in the Bank's reserve ratio leads to a decrease in the Bank's discount rate for two or three months. Increases in the reserve ratio also lead to decreases in call money rates in New York, perhaps reflecting stable money conditions in the worlds' leading financial centers at the time. Increases in the Bank of England discount rate lead to an increase in call money rates and the U.S. gold stock. The response by the gold stock would seem to contradict the predictions of the price-specie flow mechanism. However, as noted earlier, even though the Bank of England lowered their discount rate in early 1907, they continued to discriminate against American finance bills. England became a net gold importer in 1907 as they lowered the bank rate, explaining the perverse impulse response function. Most of the other impulse responses are insignificant further suggesting the predominant role of gold shocks in driving the variables in the system.

We supplement the impulse response analysis with variance decompositions that measure the percent of the forecast error variance of a given variable that can be attributed to the variables in the system. Variance decompositions for 6, 12, and 18-month forecasts are presented in Table 3. The key result from the analysis is that gold shocks explain nearly 30 percent of the forecast variance in industrial production and 18 percent of the movements in interest rates. Call interest rates, largely driven by gold shocks and Bank of England policies, explain 36 percent of the 
forecast variance in industrial production. Innovations in the gold stock explain 40 percent of the movements in wholesale prices, suggesting that the price level eventually moved higher in response to an increase in the money supply.

Different orderings in the Choleski decomposition were undertaken to analyze the robustness of the empirical results. We also estimated a specification giving GOLD the first ordering in the system followed by BERATIO, UKBANK, CALL, IP, and WPI. The economic intuition behind giving the gold stock the first ordering in the system is that it was the primary source of shocks in this period. Innovations in the gold stock explain 99 percent of the movements in output at an 18-month forecasting horizon in this specification. We also tried a model in which the Bank of England responds to financial stress, as opposed to gold shocks, originating in the U.S. market. This implies an ordering of BERATIO, CALL, UKBANK, GOLD, IP, and WPI. Again the basic tenor of the results remained unchanged with gold shocks explaining over 80 percent of the innovations in output. The impulse response functions for the two decompositions are very similar to the ones illustrated in Figure 10. We also estimated an additional model with panic dummies but the impulse responses and variance decompositions remained unchanged.

The basic message of the empirical analysis is that gold shocks had a significant impact on interest rates and industrial production that can be identified in this small sample of 60 observations with limited degrees of freedom. Moreover, the lack of significant feedback from U.S. macro variables in the system to the gold stock suggests that specie flows may have largely been from an external exogenous source--San Francisco insurance payments-- in this period. Overall, the empirical analysis is consistent with the hypothesis that real shocks have large and significant effects on the real and monetary sectors of an economy. Our results suggest that the 
San Francisco earthquake set off a chain of events that pushed the United States into a recession and ultimately, a financial panic.

\section{Conclusion}

Empirical evidence on the links between real and monetary shocks is often difficult to uncover given the endogenous interaction of the two factors. The San Francisco earthquake, on the other hand, is an identifiable exogenous real shock with a traceable impact. In our paper, we follow the impact of this disaster and estimate its effects on the American economy and financial markets. We present some stylized facts about the economic effects of a real shock. We find that real shocks have large effects on output as well as the financial and monetary sectors of an economy. The empirical and historical analysis also suggests that external shocks were an important source of financial crises in the pre-Federal Reserve era (see Canova, 1991).

Historically speaking, Congress passed the Aldrich-Vreeland Act (1908) in response to the panic; this created the National Monetary Commission and authorized banks to issue emergency currency backed by commercial paper in times of crisis. The National Monetary Commission's recommendations eventually formed the basis of the Federal Reserve Act that was passed in 1913. 


\section{References}

Andrew, A. Piatt. Statistics for the United States 1867-1909. (Washington: Garland Publishing, 1983).

Bureau of Domestic and Foreign Commerce. Monthly Summary of Commerce and Finance of the United States. (Washington: GPO, 1905-1908).

Barro, Robert J. "Money and the Price Level under the Gold Standard." Economic Journal 89 (1979), 13-33.

Bloomfield, Arthur. Monetary Policy under the International Gold Standard. (New York: Federal Reserve Bank of New York, 1959).

Bordo, Michael D. and Richard Ellson. "A Model of the Gold Standard with Depletion." Journal of Monetary Economics 16 (1985), 109-120.

Bordo, Michael D. and Antu Murshid. "Are Financial Crises Becoming More Contagious? What is the historical evidence on Contagion?" NBER Working Paper No. 7900, September 2000.

Bordo, Michael D. "The Gold Standard: The Traditional Approach." In Michael D. Bordo and Anna J. Schwartz, A Retrospective on the Classical Standard, 1821-1931." (Chicago: Chicago University Press, 1984).

Calomiris, Charles, and Gary Gorton. "The Origins of Banking Panics: Models, Facts, and Bank Regulation." In R. G. Hubbard (Ed.), Financial Markets and Financial Crises. (Chicago: Chicago University Press, 1991).

Calomiris, Charles, and R. Glenn Hubbard. "Price Flexibility, Credit Availability, and Economic Fluctuations: Evidence from the United States, 1894-1909." Quarterly Journal of Economics 54 (1989), 429-452.

Canova, Fabio. "The Sources of Financial Crisis: Pre- and Post- Fed Evidence." International Economic Review 32 (1991), 689-713.

Capie, F. and A. Webber. A Monetary History of the United Kingdom, 1870-1982. (London: George Allen and Unwin, 1985).

Clapham, John. The Bank of England. Volume II. (Cambridge: Cambridge University Press, 1944).

Clapham, John. An Economic History of Modern Britain: Free Trade and Steel. (Cambridge: Cambridge University Press, 1952). 
Cockerell, H.A.L., and Edwin Green. The British Insurance Business 1547-1970. (London: Heinemann Educational Books, 1976).

The Commercial and Financial Chronicle. New York, various years.

Cross, Ira. Financing an Empire. (Chicago: S.J. Clarke Publishing Co., 1927).

Dacy, Douglas, and Howard Kunreuther. The Economics of Natural Disaster. (New York: The Free Press, 1969).

De Long, J. Bradford. "Did Morgan's Men Add Value? An Economist's Perspective on Financial Capitalism." Inside the Business Enterprise: Historical Perspectives on the Use of Information. (Chicago: Chicago University Press, 1991).

Donaldson, R. Glenn. "Financing Banking Crises: Lessons from the Panic of 1907." Journal of Monetary Economics 31 (1993), 69-95.

Douty, Christopher. The Economics of Localized Disasters: The 1906 San Francisco Catastrophe. (New York: Arno Press, 1977).

Eichengreen, Barry. Golden Fetters. (Oxford: Oxford University Press, 1992)

The Economist. London, 1905-1908.

Financial Times. London, 1906.

Friedman, Milton and Anna Schwartz. A Monetary History of the United States 18671960. (Princeton: Princeton University Press, 1963).

Goodhart, Charles E. The New York Money Market and the Finance of Trade. (Cambridge: Harvard University Press, 1969).

Goodhart, Carles E. The Business of Banking, 1891-1914. (London: Weidenfield and Nicolson, 1972).

Haas, J. Eugene, Robert W. Kates, and Martyn J. Bowden, eds. Reconstruction Following Disaster. (Cambridge: The MIT Press, 1977).

Kennedy, John Castillo. The Great Earthquake and Fire, San Francisco, 1906. (New York: William Morrow and Company, 1963).

Kindleberger, Charles. Manias, Panics, and Crashes: A History of Financial Crises. (New York: Basic Books, 1978).

Kirschner, Herbert A. Fire Insurance Development on the Pacific Coast. (San Francisco: Underwriters' Report, 1922). 
Los Angeles Times, various issues.

Macaulay, F. R. The Movement of Interest Rates, Bond Yields, and Stock Prices in the United States since 1856. (New York: National Bureau of Economic Research, 1938.)

Miron, Jeffrey A. and Christina D. Romer. "A New Monthly Index of Industrial Production, 1884-1940." Journal of Economic History 50 (1990), 321-37.

Moen, Jon, and Ellis Tallman. "Lessons from the Panic of 1907." Federal Reserve Bank of Atlanta Economic Review 75 (1990), 2-13.

Moen, Jon, and Ellis Tallman. "Clearinghouse Membership and Deposit Contraction during the Panic of 1907." Journal of Economic History 60 (2000), 145-163.

National Research Council. The Economic Consequences of a Catastrophic Earthquake. (Washington, D.C.: National Academy, 1992).

Neal, Larry D. "A Shocking View of Economic History (Presidential Address to the Economic History Association)." Journal of Economic History 60 (2000), 317-334.

Neal, Larry D. and Marc D. Weidenmier. "Crises in the Global Economy from Tulips to Today: Contagion and Consequences " NBER Conference Project, Globalization in Historical Perspective, forthcoming University of Chicago Press.

The New York Times, various issues.

Odell, Kerry. Capital Mobilization and Regional Financial Markets: The Pacific Coast States, 1850-1920. (New York: Garland Publishing, 1992).

Phillips, Ronnie J. "Coping with Financial Catastrophe: The San Francisco Clearinghouse during the Earthquake of 1906." Manuscript, 2002.

Ramirez, Carlos. "Did J. P. Morgan's Men Add Value? Corporate Investment, Cash Flow, and Financial Structure at the Turn of the Century." Journal of Finance 50 (1995), 661-678.

Romer, Christina D. "The Prewar Business Cycle Reconsidered: New Estimates of Gross National Product, 1869-1908." Journal of Political Economy 97 (1989), 1-37.

San Francisco Examiner, various issues.

Sayers, R. S. The Bank of England 1891-1944. (Cambridge: Cambridge University Press, 1976).

Sprague, O.M. History of Crises under the National Banking System. (Washington, D.C.: National Monetary Commission, 1910). 
Stock, James H. and Mark W. Watson. "Vector Autoregressions." Journal of Economic Perspectives 15 (2001), 101-15.

Tallman, Ellis, and Jon Moen. "Gold Shocks, Liquidity, and the United States Economy during the National Banking Era." Explorations in Economic History 35 (1998), 381-404.

The Times. London, 1905-1908.

Thomas, Gordon, and Max Morgan Witts. The San Francisco Earthquake. (New York: Stein and Day, 1971).

United States Bureau of the Census. Report on Insurance Business in the United States. Eleventh Census, Extra Census Bulletin no. 6, 1891.

United States Comptroller of the Currency. Annual Reports, various years.

United States Secretary of the Treasury. Annual Report on the State of the Finances for the Fiscal Year Ended June 30, 1906. (Washington: GPO, 1906). 


\section{Endnotes}

${ }^{1}$ Neal [2000] suggests that economists should pay closer attention to the economic effects of natural disasters and climate changes.

${ }^{2}$ The GNP data are taken from Romer [1989].

${ }^{3}$ Calomiris and Hubbard find U.S. output fluctuations were largely driven by credit supply shocks during the classical gold standard period. Their model assumes the operation a pricespecie flow mechanism with rapid price adjustment and elastic gold supply. In our analysis, we assume that the price-specie flow mechanism works well except in the case of very large shocks like the San Francisco earthquake.

${ }^{4}$ Kindleberger [1978, p. 70], for example, states "gold exports as a result of American borrowing led to advances in the Bank rate in October 1906, followed by the Bank of England's advice to the market that further acceptance of American finance bills was a menace to stability and unwelcome. This slowed down the boom but failed to prevent the rich man's panic of March 1907 and the full-scale panic of October". Kindleberger [1978] also cites various other events ranging from an Italian banking failure to a Russian war loan as possible sources of the British gold outflow. It remains, however, that during this period, British gold outflows to the United States were nearly 250 percent greater than to any other country in 1906 . In their discussion of the 1907 crisis, Bordo and Murshid (2001, p. 15) note that "The trigger is said to have been the Bank of England, which began raising its discount rate in 1906 from 3.5 percent to 6 percent in response to a gold drain". A search of the Economist uncovered another potentially important event in the 1907 panic. In late December 1905, concern over the Moscow uprising and the likely impact on Russia's foreign debt caused a spike in American call loan rates. This spike, however, was not accompanied by the gold outflows from Britain that we see in the aftermath of 
the earthquake.

${ }^{5}$ Kindleberger [1978] lists the San Francisco earthquake as a possible important event leading up to the 1907 Panic in his "Stylized Outline of Financial Crises, 1618 to 1998". He does not, however, discuss the economic effects of the natural disaster in his classic book on manias and panics.

${ }^{6}$ In fact, The Economist [April 28, 1906] noted that some critics were chiding the British companies (who had underwritten very profitable San Francisco policies) for their "tendency to strain after big figures without devoting adequate consideration to the risks involved."

${ }^{7}$ The 12.5 percent figure was computed by dividing 1 billion by the NYSE market capitalization at the end of 1905. The authors thank Peter Rousseau for providing the data on NYSE market capitalization.

${ }^{8}$ Californians had developed this preference during the gold rush, and it persisted long after the state had largely tapped out its own veins of gold ore.

${ }^{9}$ This was anticipated by the editor of the Los Angeles Times who wrote, on May 1, that "It is going to tax the ability, not only of the United States, but of the civilized world under existing circumstances, to finance the enormous project of rebuilding the city of San Francisco. ..." ${ }^{10}$ The San Francisco newspapers reacted quickly and vociferously to such a suggestion. In the May 7, 1906 edition of the San Francisco Examiner, the editor wrote "To say that [insurers] will not recognize as an obligation the destruction of a building by fire, which fire was the result of an earthquake, is to take a position hardly more reputable than that of an ordinary pickpocket."

${ }^{11}$ This company consisted of four insurance firms: Norwich Union, Commercial Union, Palatine, and Alliance. 
12 Business Minutes of the CGNU Archives, March-November 1906.

${ }^{13}$ In contrast, exports to France, Egypt, India, and Argentina each amount to only 10 to 15 percent of total or seasonally adjusted British gold outflows. If we include British gold exports to France in the spring -- to shore up French reserves lost as a result of that country's relief and aid payments to the United States -- we can say that more than 42 percent of seasonally- adjusted British gold exports were quake related, and such payments to the United States would account for more than 2.5 times the British gold exports to any other country in 1906. (British gold exports were deseasonalized using the Holt-Winters exponential smoothing algorithm).

${ }^{14}$ If insurance payments by all foreign companies are totaled, the Times estimated that over $\$ 55$ million in claims were paid out in later summer and early fall. Although Britain was by far the largest foreign insurer in San Francisco, there were substantial amounts insured by France and, especially, Germany. (A few German firms were forced into bankruptcy by the disaster.) The Times estimated that non-British firms accounted for ten percent of foreign insurance payments made. The Times can also be used to pinpoint when insurance companies paid out most of their claims. It noted on August 9, 1906 that "[insurance] losses will be paid out of home funds." Nearly three weeks later, on August 29, it reported that "thirty-five companies of the 120 involved in the San Francisco disaster have paid an aggregate of $\$ 55,000,000$ in claims." Finally, on October 18, the Times wrote that "all claims have now been paid expect those arising under policies with 'earthquake clauses."'

${ }^{15}$ Data for the U.K. gold money stock are taken from Capie and Webber (1985).

${ }^{16}$ Individually, September 1906 ranks third and October 1906 ranks fourth in terms of the size of England's monthly net gold outflows between 1900 and 1913. The largest single month outflow 
during that period was in October 1907, at the height of the Panic.

${ }^{17}$ We searched the recorded minutes in the Bank's archives but located no specific statement on the reasons for raising the discount rate. The Archivist at the Bank of England, Mr. Henry Gillett, noted that the Bank of England did not record discussions of discount rate changes during this particular period in British economic history. In a lengthy December 10, 1906 letter to the Editor of The Economist, however, a correspondent signing himself "Economist" contradicts an earlier letter in which the increase in the discount rate was blamed on the Bank's "injudicious finance." "Economist" writes that ". . the causes underlying this present crisis are deeper. There are many subsidiary causes. The sudden liabilities of the British insurance companies to America in connection with the San Francisco fire is one cause ...." (p. 2053)

${ }^{18}$ The Economist, October 20, 1906.

${ }^{19}$ Typically, American banks and trust companies drew finance bills payable in pound sterling on their correspondent banks in London during the summer. They would then sell sterling bills for dollars; this would result in a gold shipment to New York. The finance bills would be covered in the autumn when the demand for dollars was high following the export of U.S. agricultural goods to Europe.

${ }^{20}$ The Economist of September 22, 1906 saw this as a reflection of the Bank's "evident desire ... to avoid, if possible, a further advance of the rate. By December 22, the editor of The Economist actually came out in favor of outright discrimination against American bills despite one correspondent's contention that such an anti-free market policy could "imperil 'our pre-eminence in the international position."' Clearly, the editor was more concerned about domestic economic conditions than international economic reputation. 
${ }^{21}$ We focus our discussion on our variables that exhibit Granger-causality in the level and difference specifications.

${ }^{22}$ We estimate the VAR in levels to use all available information in the system. Similar results are obtained in differences and are available from the authors by request.

${ }^{23}$ Extending the impulse responses beyond 12 months was not very informative as the confidence intervals became very large and bounded zero in every case. The confidence intervals are generated by 500 draws of Monte Carlo integration procedure performed using the RATS computer software. 


\section{Table 1}

Company

Alliance

Atlas (\& subsidiaries)

Caledonian and Cal.-American

Commercial Union and Palatine

Law Union

Liverpool and London and Globe

London Assurance

London and Lancashire and Orient

North British

Northern

Norwich Union

Phoenix and Pelican

Royal and Queen

Royal Exchange

Scottish Union and National

Sun

Union

TOTAL
Value of San Francisco

Policies in Effect (\$)

$3,526,220$

$6,790,000$

$5,457,727$

$7,802,722$

$2,205,290$

$4,850,000$

$7,668,471$

$9,662,291$

$4,021,943$

$4,238,646$

$2,716,097$

$5,000,948$

$9,044,050$

$5,518,342$

$2,013,185$

$3,122,091$

$\underline{4,238,775}$

$87,877,678$
Estimated Losses (\$)

$1,758,686$

2,757,957

$1,521,064$

$4,116,281$

$1,368,460$

$3,998,000$

$4,016,471$

$4,229,721$

$3,012,500$

$2,063,926$

750,030

$2,808,313$

$5,787,776$

$2,639,564$

$1,300,000$

$1,651,666$

$\underline{2,345,420}$

$46,125,835$ 
Table 2

Granger-Causality Tests

F-Tests for Levels [Differences]

\begin{tabular}{|c|c|c|c|c|c|c|}
\hline \multirow[b]{2}{*}{$\begin{array}{l}\text { DEPENDENT } \\
\text { VARIABLE } \\
\end{array}$} & \multicolumn{6}{|c|}{ INDEPENDENT VARIABLE } \\
\hline & BERATIO & GOLD & BANK & CALL & IP & WPI \\
\hline BERATIO & $\begin{array}{l}1.720 \\
{[3.313]^{* *}}\end{array}$ & $\begin{array}{l}1.266 \\
{[2.687]^{*}}\end{array}$ & $\begin{array}{l}1.003 \\
{[2.623]^{*}}\end{array}$ & $\begin{array}{l}2.733^{*} \\
{[4.090]^{* *}}\end{array}$ & $\begin{array}{l}1.161 \\
{[2.328]}\end{array}$ & $\begin{array}{l}1.356 \\
{[2.926]^{*}}\end{array}$ \\
\hline GOLD & $\begin{array}{l}4.363 * * \\
{[2.445]^{*}}\end{array}$ & $\begin{array}{l}23.846 * * * \\
{[0.853]}\end{array}$ & $\begin{array}{l}2.953^{*} \\
{[1.685]}\end{array}$ & $\begin{array}{l}2.240 \\
{[0.542]}\end{array}$ & $\begin{array}{l}1.182 \\
{[0.323]}\end{array}$ & $\begin{array}{l}0.874 \\
{[0.927]}\end{array}$ \\
\hline BANK & $\begin{array}{l}1.139 \\
{[0.439]}\end{array}$ & $\begin{array}{l}0.318 \\
{[0.908]}\end{array}$ & $\begin{array}{l}1.419 \\
{[0.910]}\end{array}$ & $\begin{array}{l}1.239 \\
{[0.487]}\end{array}$ & $\begin{array}{l}0.733 \\
{[0.903]}\end{array}$ & $\begin{array}{l}0.852 \\
{[0.366]}\end{array}$ \\
\hline CALL & $\begin{array}{l}1.650 \\
{[1.328]}\end{array}$ & $\begin{array}{l}3.839^{* *} \\
{[4.043]^{* *}}\end{array}$ & $\begin{array}{l}0.977 \\
{[1.256]}\end{array}$ & $\begin{array}{l}1.108 \\
{[1.151]}\end{array}$ & $\begin{array}{l}1.478 \\
{[2.302]}\end{array}$ & $\begin{array}{l}1.174 \\
{[0.889]}\end{array}$ \\
\hline IP & $\begin{array}{l}3.390^{* *} \\
{[4.631]^{* *}}\end{array}$ & $\begin{array}{l}3.207^{* *} \\
{[3.415]^{* *}}\end{array}$ & $\begin{array}{l}0.637 \\
{[1.347]}\end{array}$ & $\begin{array}{l}5.477 * * * \\
{[5.644] * * *}\end{array}$ & $\begin{array}{l}9.409 * * * \\
{[3.774]^{* *}}\end{array}$ & $\begin{array}{l}2.677 * * \\
{[3.272]^{* *}}\end{array}$ \\
\hline WPI & $\begin{array}{l}1.265 \\
{[0.631]}\end{array}$ & $\begin{array}{l}1.751 \\
{[1.463]}\end{array}$ & $\begin{array}{l}0.543 \\
{[0.510]}\end{array}$ & $\begin{array}{l}1.253 \\
{[0.954]}\end{array}$ & $\begin{array}{l}1.945 \\
{[2.382]}\end{array}$ & $\begin{array}{l}4.938 * * * \\
{[1.023]}\end{array}$ \\
\hline
\end{tabular}

***denotes significance at the 1 percent level.

$* *$ denotes significance at the 5 percent level.

*denotes significance at the 10 percent level. 
Table 3

Forecast Error Variance Decomposition (FEVD)

FEVD for BOERATIO

\begin{tabular}{|c|c|c|c|c|c|c|}
\hline $\begin{array}{c}\text { Horizon } \\
\text { (std. error) }\end{array}$ & BERATIO & GOLD & UKBANK & CALL & IP \\
\hline $\begin{array}{c}\mathbf{6} \\
(3.25)\end{array}$ & 36.81 & 14.02 & 9.30 & 20.96 & 11.31 \\
\hline $\begin{array}{c}\mathbf{1 2} \\
(4.78)\end{array}$ & 19.28 & 17.63 & 8.31 & 26.98 & 19.08 \\
\hline $\begin{array}{c}\mathbf{1 8} \\
(8.73)\end{array}$ & 6.20 & 25.45 & 3.77 & 32.95 & 25.25 \\
\hline
\end{tabular}

FEVD for GOLD

\begin{tabular}{|c|c|c|c|c|c|c|}
\hline $\begin{array}{c}\text { Horizon } \\
\text { (std. error) }\end{array}$ & BERATIO & GOLD & UKBANK & CALL & WPI \\
\hline $\begin{array}{c}\mathbf{6} \\
(0.02)\end{array}$ & 4.08 & 13.37 & 66.73 & 5.55 & 9.22 \\
\hline $\begin{array}{c}\mathbf{1 2} \\
(0.05)\end{array}$ & $\mathbf{2 . 1 4}$ & 16.96 & 17.01 & 29.28 & 33.43 \\
\hline $\mathbf{1 8}$ & $\mathbf{0 . 6 2}$ & 21.75 & 6.17 & 34.47 & 33.96 \\
\hline
\end{tabular}

FEVD for UKBANK

\begin{tabular}{|c|c|c|c|c|c|c|}
\hline $\begin{array}{c}\text { Horizon } \\
\text { (std. error) }\end{array}$ & BERATIO & GOLD & UKBANK & CALL & WPI \\
\hline $\begin{array}{c}\mathbf{6} \\
(0.53)\end{array}$ & 21.24 & 3.20 & 50.82 & 15.34 & 6.65 \\
\hline $\begin{array}{c}\mathbf{1 2} \\
(0.68)\end{array}$ & 20.94 & 3.95 & 45.82 & 12.91 & 14.18 \\
\hline $\begin{array}{c}\mathbf{1 8} \\
(0.89)\end{array}$ & 13.05 & 10.15 & 26.83 & 20.16 & 11.68 \\
\hline
\end{tabular}


Table 3 (cont.)

FEVD for CALL

\begin{tabular}{|c|c|c|c|c|c|c|}
\hline $\begin{array}{c}\text { Horizon } \\
\text { (std. error) }\end{array}$ & BERATIO & GOLD & UKBANK & CALL & IP \\
\hline $\begin{array}{c}\mathbf{6} \\
(2.20)\end{array}$ & 14.97 & 19.28 & 25.22 & 28.77 & 8.64 \\
\hline $\begin{array}{c}\mathbf{1 2} \\
(2.94)\end{array}$ & 17.05 & 15.22 & 26.80 & 21.17 & 9.04 \\
\hline $\begin{array}{c}\mathbf{1 8} \\
(3.46)\end{array}$ & 12.85 & 18.16 & 22.21 & 23.04 & 10.73 \\
\hline
\end{tabular}

FEVD for IP

\begin{tabular}{|c|c|c|c|c|c|c|}
\hline $\begin{array}{c}\text { Horizon } \\
\text { (std. error) }\end{array}$ & BERATIO & GOLD & UKBANK & CALL & IP \\
\hline $\begin{array}{c}\mathbf{6} \\
(0.08)\end{array}$ & 2.90 & 29.55 & 7.80 & 32.13 & 26.48 \\
\hline $\begin{array}{c}\mathbf{1 2} \\
(0.15)\end{array}$ & 2.06 & 31.97 & 3.74 & 35.77 & 24.28 \\
\hline $\mathbf{1 8}$ & & & 5.15 & \\
$(0.20)$ & 1.27 & 29.46 & 5.68 & 36.00 & 22.38 \\
\hline
\end{tabular}

FEVD for WPI

\begin{tabular}{|c|c|c|c|c|c|c|}
\hline $\begin{array}{c}\text { Horizon } \\
\text { (std. error) }\end{array}$ & BERATIO & GOLD & UKBANK & CALL & WPI \\
\hline $\begin{array}{c}\mathbf{6} \\
(0.005)\end{array}$ & 2.27 & 35.90 & 0.72 & 28.28 & 30.37 \\
\hline $\begin{array}{c}\mathbf{1 2} \\
(0.01)\end{array}$ & 1.03 & 39.76 & 1.70 & 32.83 & 22.44 \\
\hline $\begin{array}{c}\mathbf{1 8} \\
(0.01)\end{array}$ & 0.71 & 39.80 & 1.92 & 34.35 & 18.56 \\
\hline
\end{tabular}


Figure 1

US Net Gold Imports 1900-1913

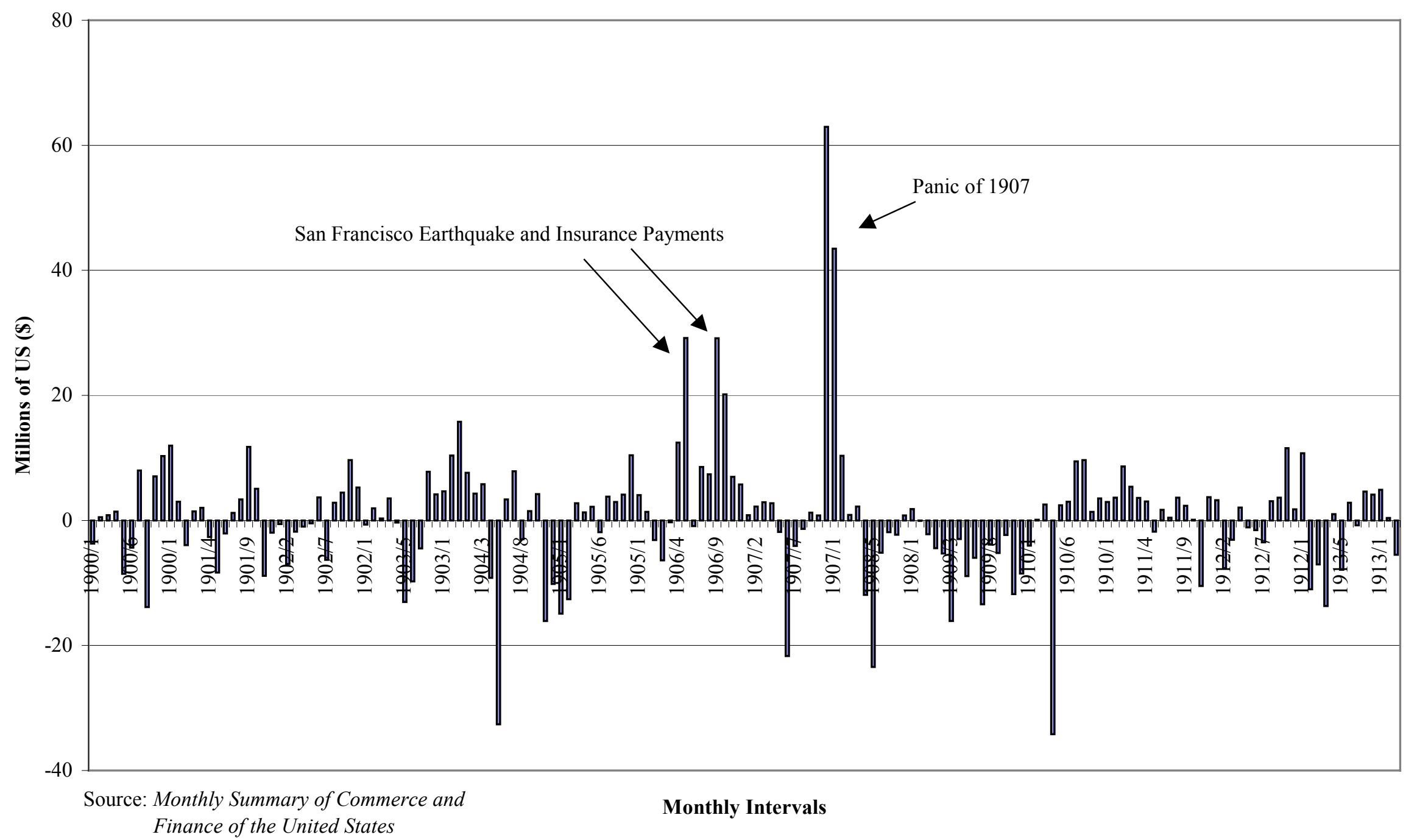


Figure 2

UK Gold Exports to US 1900-1913

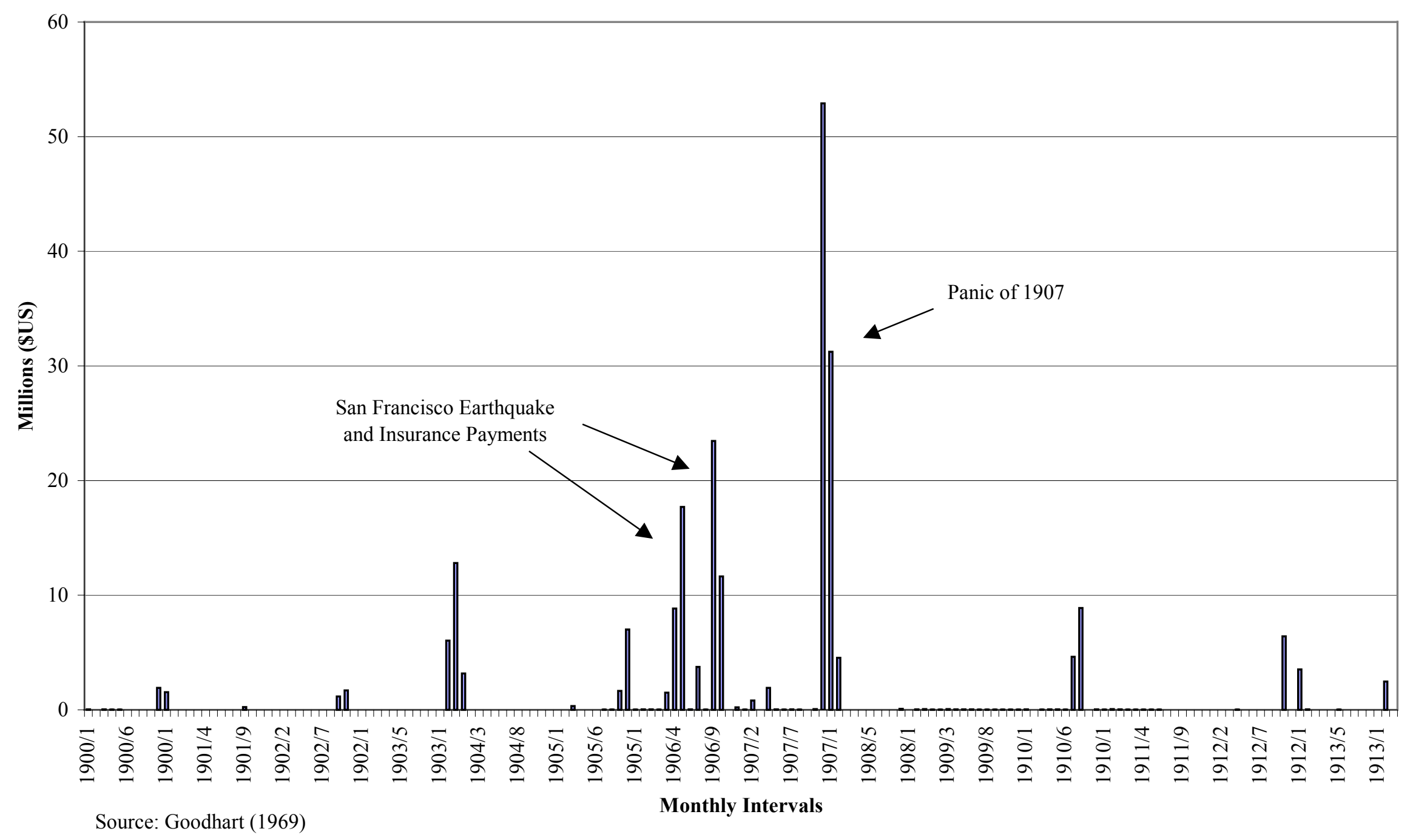


Figure 3

San Francisco Gold Imports 1905 - 1908

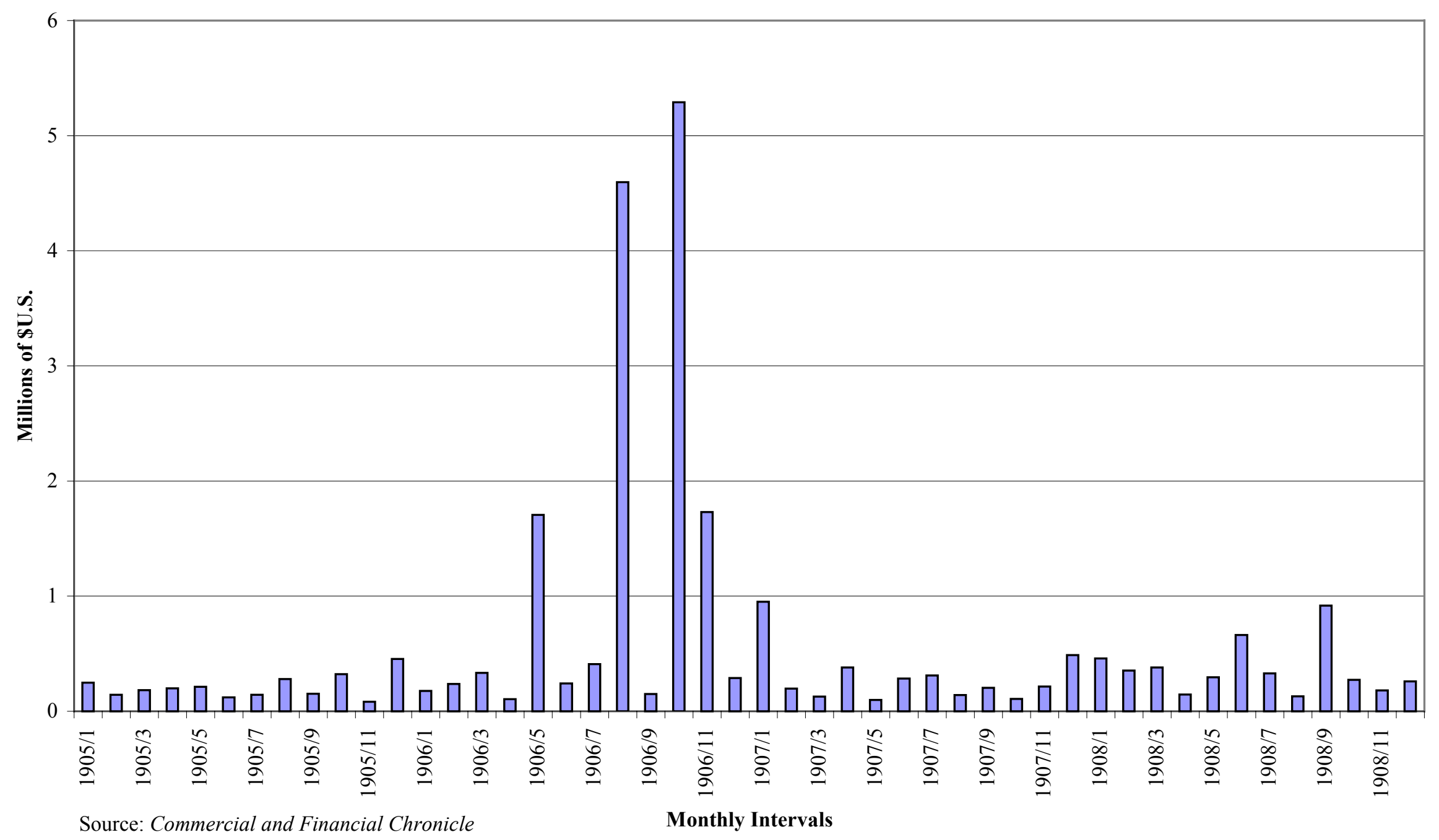


Figure 4

Bank of England Net Gold Flows 1900-1913

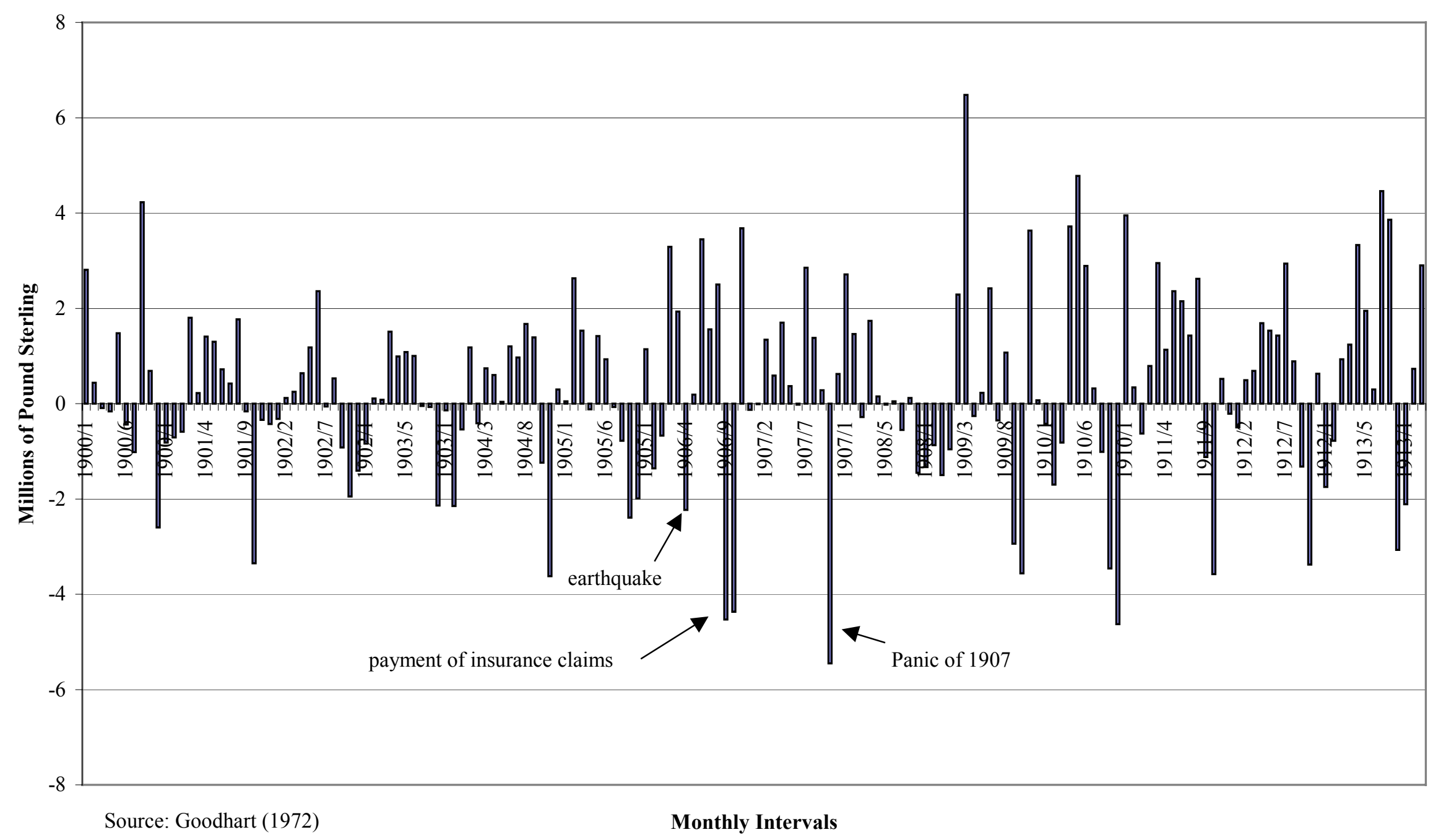


Figure 5

Discount Rates for London, Paris, and Berlin 1900-1913

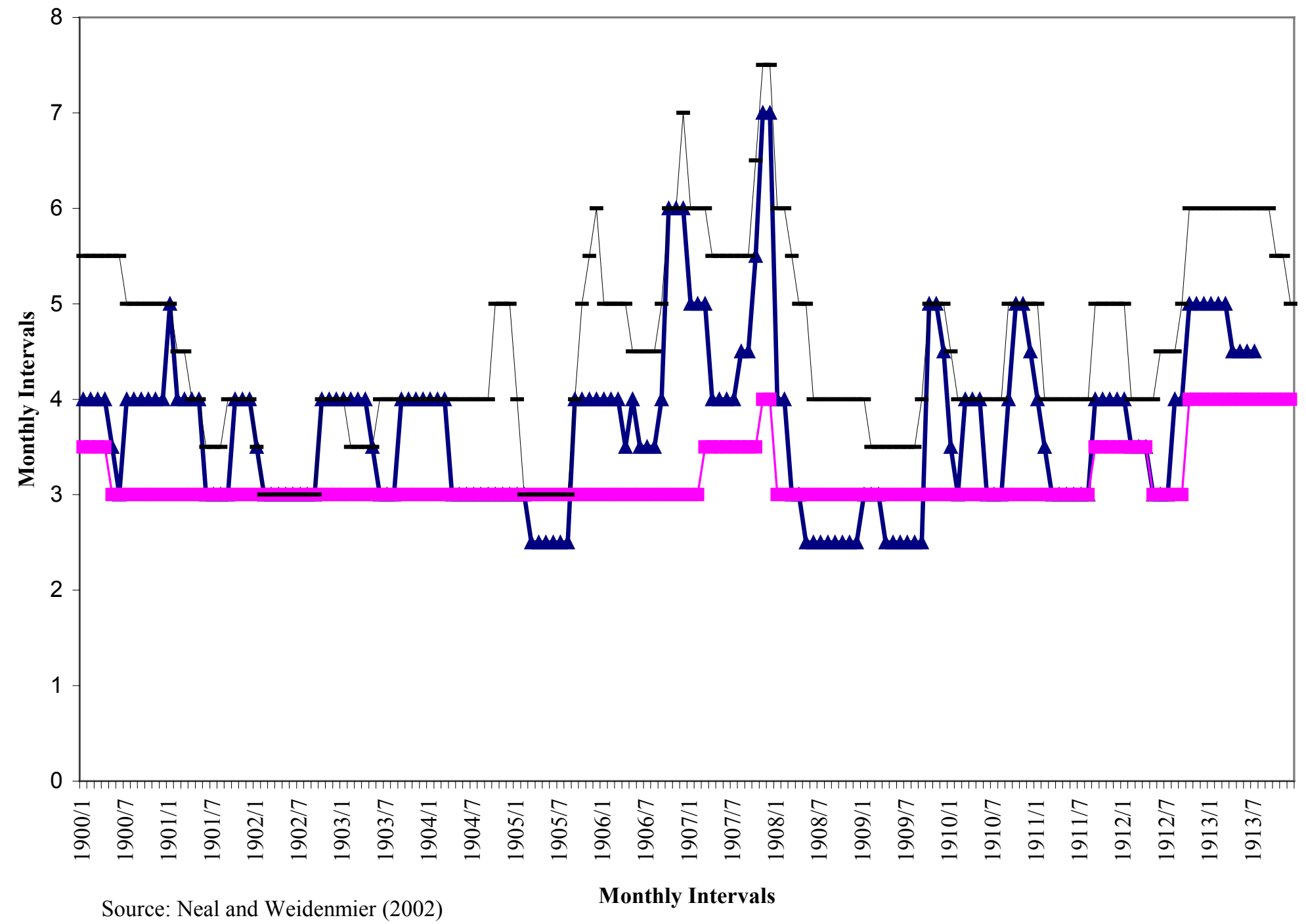

$\rightarrow$ London $\rightarrow$ - Paris 
Figure 6

UK Net Gold Imports 1900-1913

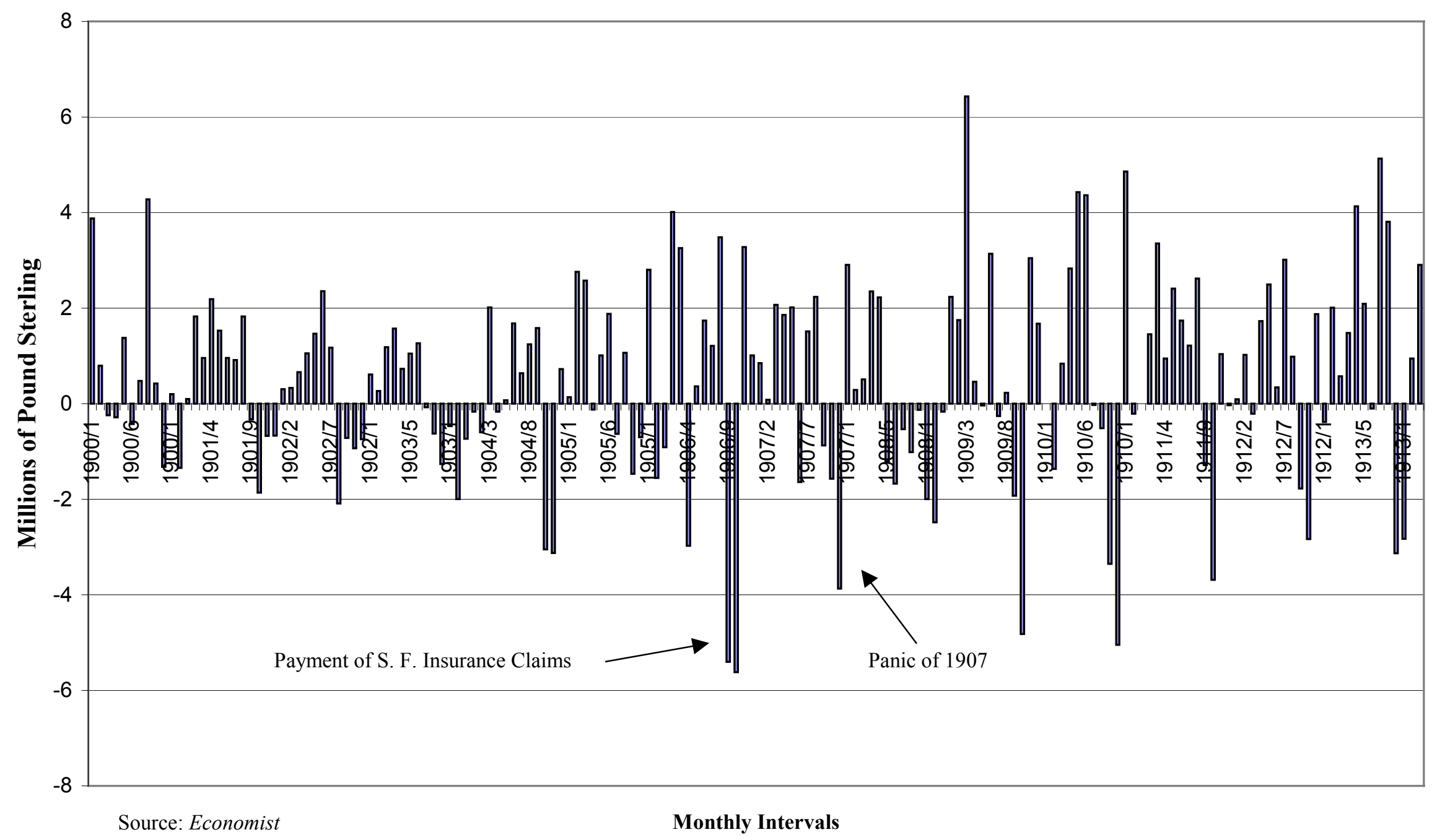


Figure 7

US Gold Money Supply 1900-1909

(in natural logarithms)

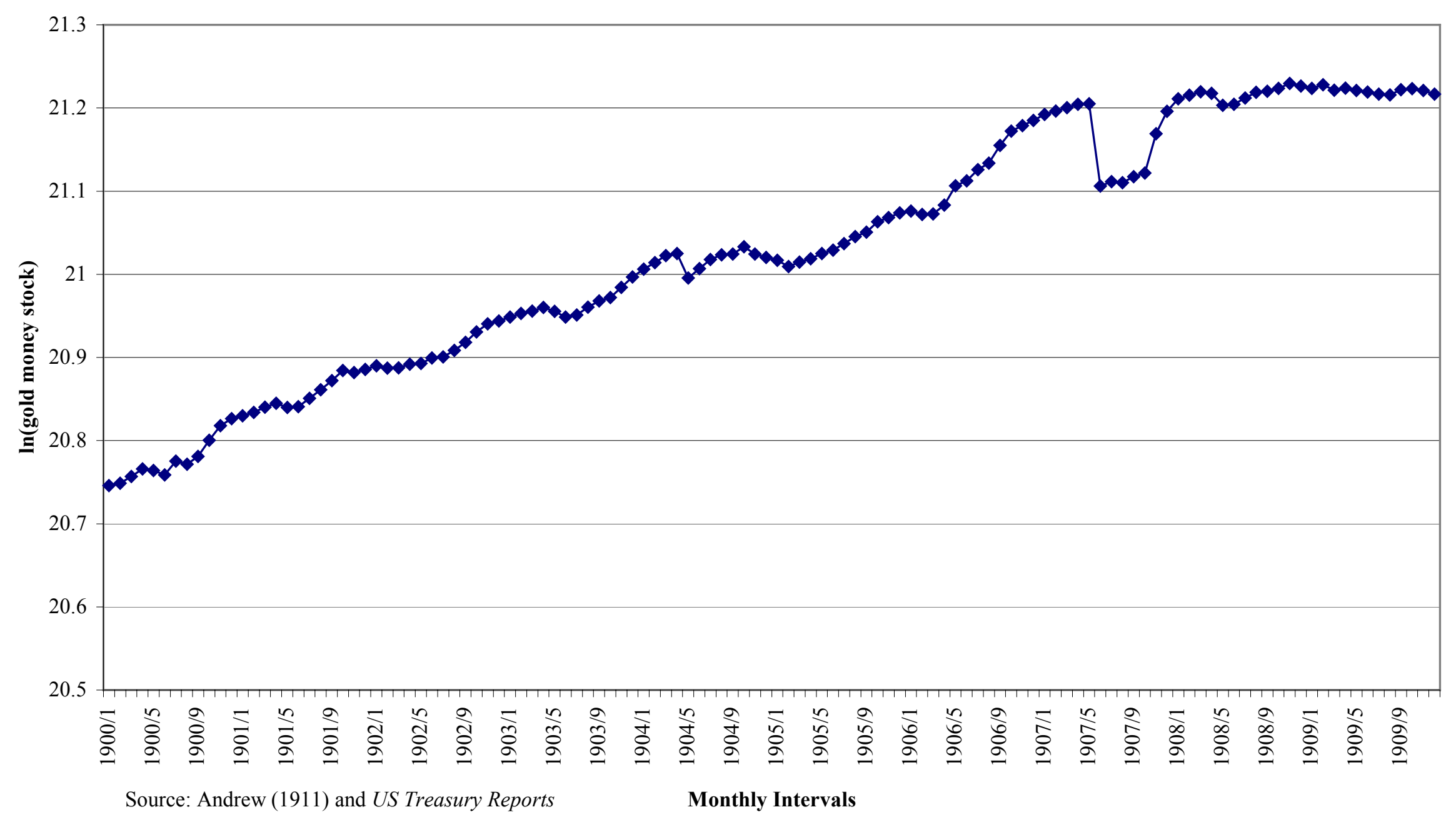


Figure 8

US Industrial Production 1900-1913

(in natural logarithms)

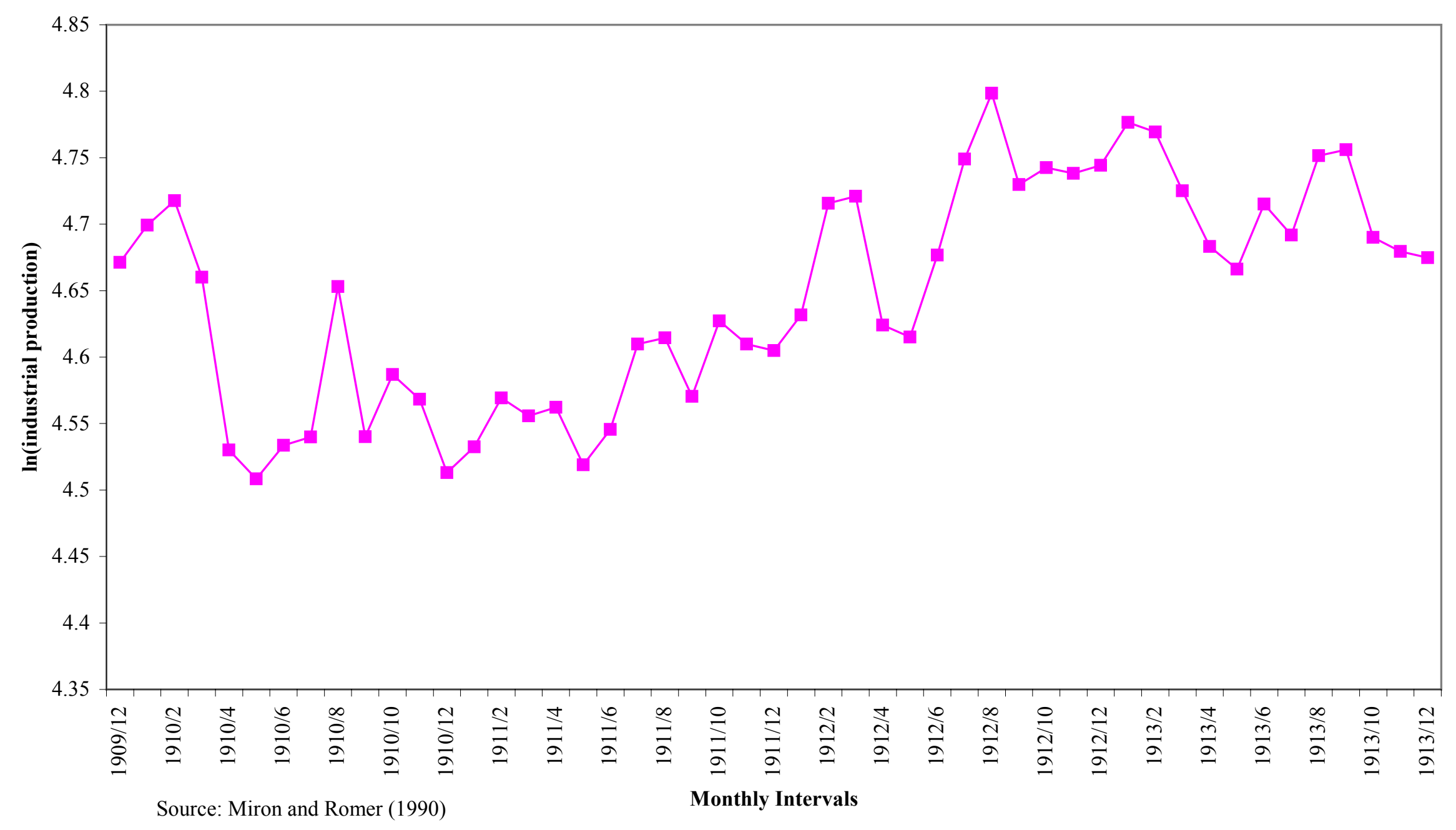


Figure 9

New York Call Money Rates 1900-1913

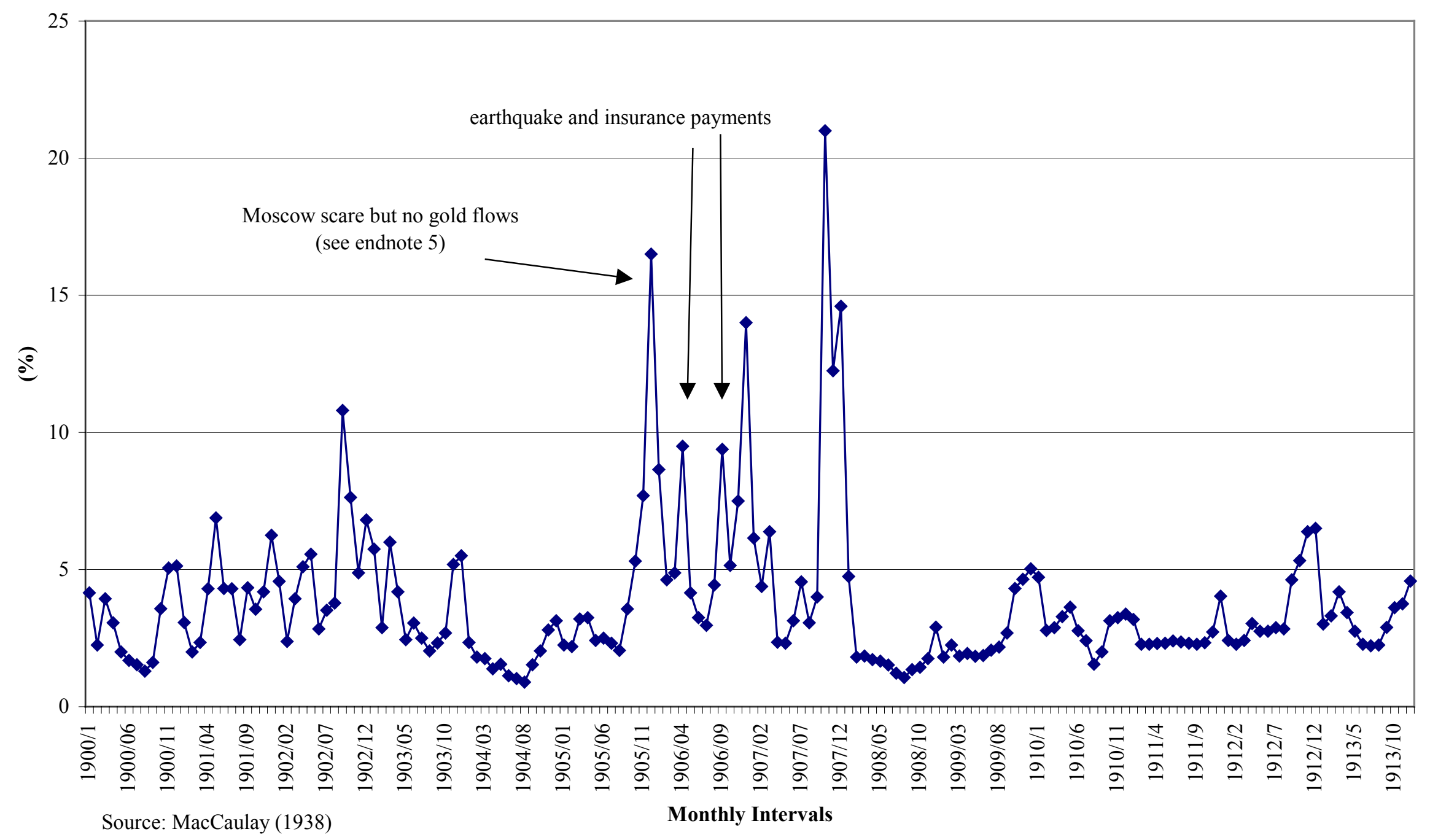




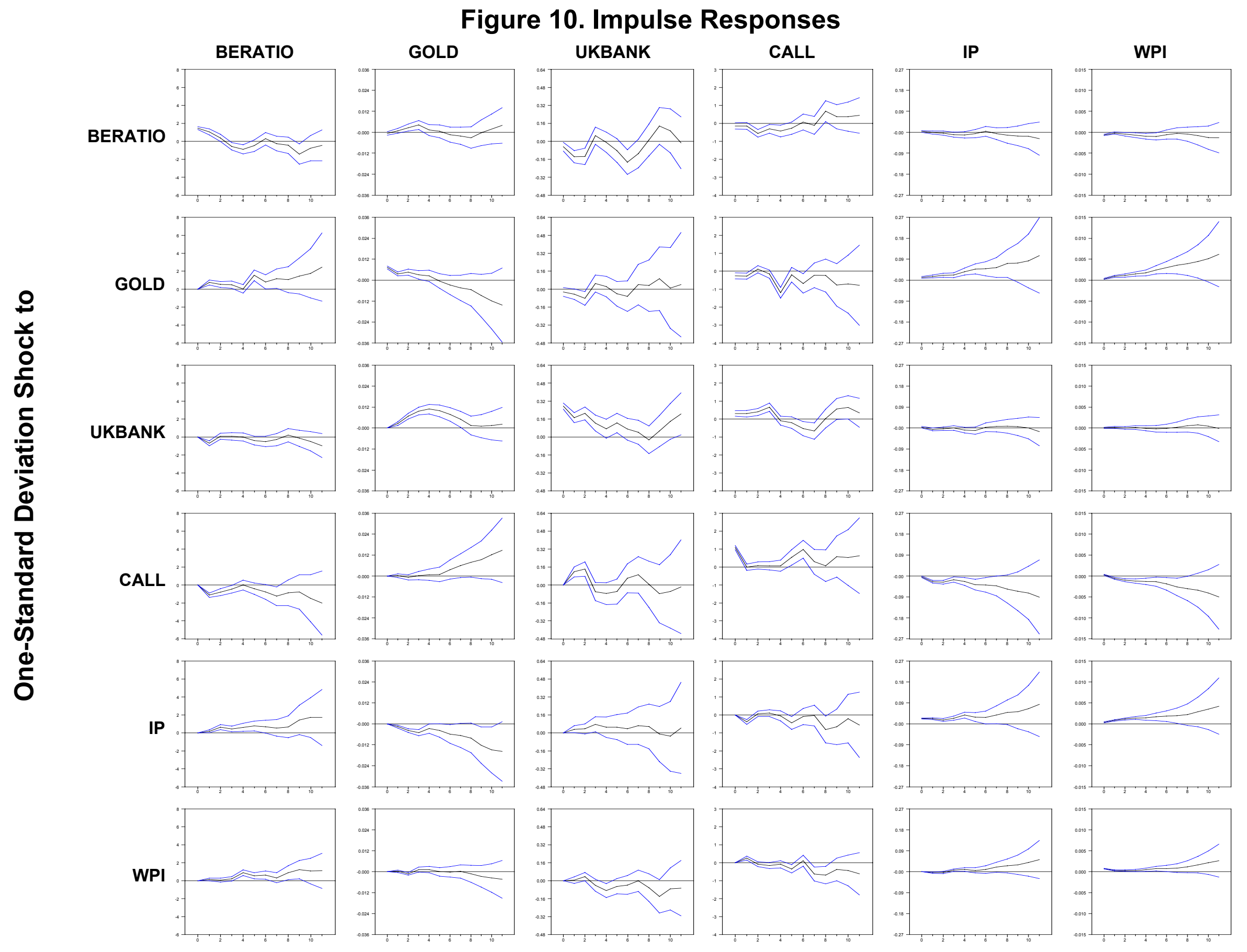


